\title{
Türk Sigortacılık Sektöründe Hayat Dışı Sigorta Şirketlerinin Etkinlik Analizi*
}

\author{
Illknur Külekçi ${ }^{1}$ (D) , Arif Saldanlı ${ }^{2}$
}

Öz

Sigortacılık sektörünün finansal sistemde önemli bir yeri vardır. Türkiye'de sigortacllık sektörü gelişmekte olan bir sektördür. Hayat dışı sigorta şirketleri ise hayat sigorta ve emeklilik şirketleri ile karşılaştrıılığında daha büyük paya sahiptir. Çalışmada 2011-2015 yılları arasında sürekli verisi elde edilebilen hayat dışı sigorta şirketlerinin etkinliği veri zarflama yöntemiyle analiz edilmektedir. Çalışma kapsamında sigorta şirketlerinin etkinliği önce toplamsal VZA yöntemiyle analiz edilmiştir. Analizin sonuçlarına göre çıktı odaklı CCR VZA modeli ile analiz yapılmıştr. Analiz dönemi içerisinde 30 KVB'nin 18 tanesi hiç etkin sınıra ulaşamamıştr. Etkin bulunan şirket oranının en çok olduğu yıl \% 30 ile 2012 yılı, en düşük olduğu yıl ise \%10 ile 2014 yılı olarak gerçekleşmiştir.

\author{
Anahtar Kelimeler \\ Hayat Dışı Sigorta Şirketleri • Veri Zarflama Analizi • Toplamsal VZA Yöntem • Çıktı Odaklı CCR VZA • Etkinlik \\ JEL Classifications \\ $\mathrm{G} 14 \cdot \mathrm{G} 24$
}

Efficiency Analysis of Non-Insurance Insurance Companies In The Turkish Insurance Sector

\begin{abstract}
The insurance sector has an important place in the financial system. Insurance sector in Turkey is an emerging industry. Non-life insurance companies have a larger share compared to life insurance and pension companies. In the study, the efficiency of non-life insurance companies, which can be obtained continuously between 2011 and 2015, is analyzed with data envelopment method. In the scope of the study, the effectiveness of insurance companies was first analyzed by the additive DEA method. According to the results of the analysis, an output-oriented CCR VZA model was analyzed. During the analysis period, 18 of the $30 \mathrm{DMU}$ did not reach the effective limit. The highest rate was found in 2012 with $30 \%$ and the lowest in 2014 with $10 \%$.
\end{abstract}

\section{Keywords}

Non-Life Insurance Companies • Data Envelopment Analysis • Multi-Stage Dea Model • Output Oriented CCR DEA - Efficiency

\section{JEL Classifications}

$\mathrm{G} 14 \cdot \mathrm{G} 24$

\footnotetext{
* Bu çalışma İlknur Külekçi tarafindan İstanbul Üniversitesi Sosyal Bilimler Enstitüsü, Para Sermaye Piyasaları ve Finansal Kurumlar Bilim Dalında Dr. Öğr. Üyesi Arif Saldanlı danışmanlığında hazırlanan “Türk Sigortacılık Sektöründe Hayat Dışı Sigorta Şirketlerinin Etkinlik Analizi" başlıklı tez çalışmasından yararlanılarak hazırlanmıştır.

1 Sorumlu Yazar: İlknur Külekçi (Öğr. Gör.), illknur Külekçi, Ataşehir Adıgüzel Meslek Yüksekokulu, Finans, Bankacılık ve Sigortacılık Bölümü, Bankacılık ve Sigortacılık Programı, İstanbul, Türkiye. Eposta: ilknurkulekci@yahoo.com

2 Arif Saldanlı (Öğr. Gör.), İstanbul Üniversitesi, İktisat Fakültesi, İşletme Bölümü, İstanbul, Türkiye. Eposta: saldanli@istanbul.edu.tr Atıf: Külekçi, İ. ve Şaldanlı, A. (2018), Türk sigortacılık sektöründe hayat dışı sigorta şirketlerinin etkinlik analizi. Ekoist: Journal of Econometrics and Statistics, 14(29), 225-246. https://doi.org/10.26650/ekoist.2018.14.29.0015
} 


\section{Extended Summary}

Insurance is a system for which the primary objective is to provide trust in the society. This system gathers a large number of people who are exposed to the same risk in society. Insurance is a risk management tool. These risk transfer operations are carried out by policies. The parties of a policy are insured, insurer and insurant. Insurance companies, as insurers, receive a certain amount of premium from the insured in return for the risks that they have taken over. The number of insurance companies is higher than the number of the insured. Although there are not many insurance companies, the total amount of premium collected from insured people is quite high. A certain portion of the premiums obtained regularly are utilized by the companies directing them to the financial system. This is what makes the position of insurance companies important within the financial system. Insurance companies play a key role for developing economies. Therefore, it is important that these means are used efficiently.

Main purpose and function of insurance is to provide trust in society while it is not its only function. Providing trust is just one of many functions of the insurance business. Insurance should not be considered as a simple system in which insurance companies use the premiums they collected to compensate the insured when risk occurs. However, it is a fact that premiums collected by insurance companies are their only source of income. They make good use of these premiums in the financial system to increase their effectiveness evaluating the financial system. Although companies have high effects on the financial system, their efficiency is important due to being few in number. According to 2018 data obtained by the Insurance Association of Turkey, there are 39 companies specialised in non-life insurance, 23 companies specialised in life and pensions and 2 reinsurance insurance company in our country.

Companies can measure their efficiency and learn their position in the competitive environment. Data Envelopment Analysis is a non-parametric method. In other words, it does not make an estimate of the universe for a small sample. Data envelopment analysis can be performed in an input- and output-oriented way. The method to meet the need is decided in accordance with the purpose of study. If a particular output level is to be measured, an input-oriented efficiency measurement is performed. In the input-oriented analysis, amount of output is kept fixed to calculate how much amount of input can be changed. In the output-oriented analysis, how much amount of output can be changed for a certain input. Companies can be provided with recommendations by calculating how much the insurance companies need to change their inputs and outputs in percentage at the end of the efficiency. Yet, different results can be achieved with other criteria as a respective analysis is performed with this method.

Given the data of T.R. Undersecretariat of Treasury, the number of policies and amount of premiums in non-life insurance is higher than the data of life insurance or pension. Hence, this study analyses the efficiencies of non-life insurance companies in Turkey. 
According to the literature in our country and in our world, data envelopment analysis is utilized in the studies examining the efficiencies of the insurance sector. The data were analysed with the additive model method of the data envelopment analysis method in the first place. The achieved results are aimed at making changes in outputs. In accordance, an output-oriented data envelopment analysis was decided. It is also observed in the literature that data analysis analysis is performed rather as output-oriented. The efficiencies of non-life insurance companies in Turkey will be examined using the data envelopment analysis. The data from years 2011-2015 will be utilized. The data to be used are obtained from the Activity Reports of Insurance and Individual Pension published by T.R. Undersecretariat of Treasury. The analysis were performed on the Win4DEAP software of which foundations was laid by Tim Coelli. The aim was to present a source for those who want to be informed of non-life insurance companies' efficiencies in Turkey and will contribute to the literature with the findings achieved in the analysis. 


\section{Giriş}

Sigorta temel amacı toplumda güveni sağlamak olan bir sistemdir. Bu sistemle toplumda aynı riske maruz kalan birçok kişi bir araya gelmektedir. Kısaca sigortalıların risklerini yönetmek için sigortacılara devrettiği bir risk yönetim aracıdır. Bu risk devri işlemleri poliçe aracılığıyla gerçekleştirilmektedir. Poliçenin tarafları ise sigortalı, sigortacı ve sigorta ettirendir. Sigortacılar sigortalama işini yapan sigorta şirketleri devraldıkları risklerin karşılı̆̆ında sigorta ettirenlerden belirli bir miktar prim alırlar. Sigorta şirketlerinin sayısı sigortalıların sayısıyla karşılaştırıldığında fazla değildir. Ancak sayı olarak az olmalarına rağmen sigortacıların sigortalılardan topladıkları primler bir araya geldiğinde büyük rakamlar oluşturmaktadır. Düzenli olarak elde edilen bu primlerin belirli bir kısmı şirketler tarafindan finansal sisteme yönlendirilerek değerlendirilir. Sigorta şirketlerinin finansal sistemdeki önemli yeri buradan ileri gelmektedir.

Sigortanın temel amacı ve işlevi toplumda güveni sağlamak olsa da tek işlevi bu değildir. Güven sağlamak sigortacıllğın birçok işlevinden sadece birisidir. Sigorta, sigorta şirketlerinin sadece topladıkları primleri risk gerçekleştiğinde sigortalılara tazminat ödemek için kullandığı basit bir sistem olarak düşünülmemelidir. Ancak şu bir gerçektir ki sigorta şirketlerinin tek gelir kaynağ 1 elde ettikleri primlerdir. Bu primleri finansal sistemde değerlendirerek de finansal sistemin etkinliğini arttırırlar. Şirketlerin finansal sistemdeki etkileri yüksek olmasına rağmen sayıları az olduğu için etkinlikleri önem teşkil etmektedir. Türkiye Sigorta Birliği'nin 2018 yılı verilerine göre ülkemizde 39 hayat dışı, 23 hayat ve emeklilik alanlarında faaliyet gösteren ve 2 reasürans sigorta şirketi vardır.

Şirketler etkinlik ölçümü yaparak içinde bulundukları rekabet ortamında konumlarını öğrenebilirler. Veri zarflama analizi parametrik olmayan bir yöntemdir. Yani ele aldığ az sayıdaki örneklem için anakütleye dair tahminde bulunmaz. Veri zarflama analizi girdi odaklı ve çıktı odaklı olarak yapılabilir. Çalışmanın amacına göre ihtiyacı karşılayacak olan yöntem seçilir. Belirli bir çıktı düzeyi ölçülmek isteniyorsa girdi odaklı etkinlik ölçümü yapılır. Girdi odaklı analizde çıktı miktarı sabit tutularak girdi miktarının ne kadar değiştirilebileceği hesaplanır. Çıktı odaklı etkinlik ölçümünde ise belirli bir girdi için çıktı miktarının ne kadar değiştirilebileceği hesaplanır. Etkinlik incelemesinin sonucunda şirketlerin girdi ve çıtılarını yüzdesel olarak ne kadar değiştirmeleri gerektiği hesaplanarak şirketlere önerilerde bulunulabilir. Ancak bu yöntemle göreli analiz yapıldığg için başka kısıtlarla farklı sonuçlarda elde edilebilir.

T.C. Hazine Müsteşarlığı'nın verilerine bakıldığında ise hayat dışı sigorta branşlarındaki sigorta poliçe sayısı ve prim miktarı hayat sigorta veya emeklilik verilerine kıyasla daha fazla olduğu görülmektedir 


\section{Sigortacılık Sektörü}

Sigortacılığa ilişkin kurallar Türk Ticaret Kanunu'nun 6. Kitabı'nda ve 5684 sayılı Sigortacılık Kanunu'nda yer almaktadır. Tarafların birbirlerine karşı yükümlülüklerinin belirlendiği poliçe ile sigortacının prim karşılığında güvence verdiği riskler gerçekleştiği takdirde tazminat ödeme yükümlülüğü doğar (Karaman, 2014, s. 11). Bu nedenden dolayı sigortacılık sisteminin temelinde güven esası yer almaktadır (Duygulu, 2012 s. 2).

Prim; sigorta ettirenin sigortacıya ödemekle yükümlü olduğu parasal karşılık olarak tanımlanabilmektedir. Prim, sigorta matematiğine göre hesaplanır ve ödenecek tazminatla doğrudan ilişkilidir. Sigortacının tazminat yükümlülügüünü başlatan unsur, primin ödenmiş olmasıdır. Bu da primi sigortacılık işleyişinde önemli unsurlardan birisi haline getirir (Eledelekoğlu, 2012, s. 204). Sigorta priminin hesaplanabilmesi için riskin istatistiksel olarak ölçülebilir olması gerekir. Ortak riske maruz kalan çok sayıda kişi olmalıdır (Baştürk, Çakmak ve Demirtaş, 2017 s. 33).

Sigortacılık sektörünün tarihsel gelişimine bakıldığında Osmanlı döneminde çok büyük ilerleme kaydedilmemiş olduğu görülmektedir (Yanık, 2016, s. 6-8). Bu durumun temel nedenleri olarak çöküş döneminde olan ve savaşlarla yıpranan ülkede halkın alım gücünün düşük olması ve sigortanın temel ihtiyaç olmaması sebebiyle talep edilmemesi gösterilebilir. Ayrıca halkın sigorta konusunda bilinçli olmaması ve dini motifler, toplumun yapısında yardımlaşmanın olması sigortanın ihtiyaç olarak görülmemesine etkili olan diğer unsurladır. Cumhuriyet'in ilanından sonra her alanda olduğu gibi finans sektöründe de millileşmeye gidilmiş ve daha önce yaşanmış olan engellerin önüne geçilmeye çalışılmıştır. Bu sebeple çeşitli yasalar hazırlanmıştır (Akbay, 2014, s. 76-77).

Sigorta sisteminin gelişmesi ve insanların farklı ihtiyaçlarının ortaya çıkmasıyla birlikte yeni sigorta branşları doğmuştur. Sigorta konusuna göre sınıflandırıldığında hayat ve hayat dışı olarak ayrılmaktadır. Hayat sigortaları insan hayatı, bedeni bütünlüğü ve sağlığını ilgilendiren sigortalardır. Hayat dışı sigortalar, insan hayatı ve sağlığını ilgilendiren sigortaların dışında kalan tüm sigorta branşlarını kapsamaktadır.

İnsanlar gelecekte gerçekleşebilecek tehlikelere karşı önlem alma eğilimindedirler ve doğaları gereği uzun yıllar yaşayıp yaşlanacakları gün için önlem alırlar. Yaşlandıklarında eskisi gibi çalışamayacakları için hayatlarına aynı şekilde devam edemezler. Bu sebeple henüz genç ve çalışabilecek durumda iken yaşlanacakları günler için önlem almaya başlarlar. Emeklilik yaşlanma riskine karşı önlem almak için oluşturulmuş bir sistemdir (Güzel, Okur, \& Caniklioğlu, 2012, s. 22).

Tablo 1'de görüldüğü gibi Türkiye'nin prim üretimi her yıl artmıştır. Hayat dış1 prim üretimi ise hayat sigorta branşlarına göre oransal olarak 2011 yılından 2015'e kadar oransal olarak artış göstermiştir. 
Tablo 1

Türkiye Prim Üretimi (Milyar TL) (2011-2015)

\begin{tabular}{lccccc}
\hline & $\mathbf{2 0 1 1}$ & $\mathbf{2 0 1 2}$ & $\mathbf{2 0 1 3}$ & $\mathbf{2 0 1 4}$ & $\mathbf{2 0 1 5}$ \\
\hline $\begin{array}{l}\text { Hayat Dişı } \\
\text { Branşlar }\end{array}$ & 14,5 & 17,1 & 20,8 & 22,7 & 27,3 \\
Hayat Branşları & 2,7 & 2,7 & 3,4 & 3,3 & 3,8 \\
Hayat Diş1/ & 5,37 & 6,33 & 6,12 & 6,88 & 7,18 \\
Hayat & 17,2 & 19,8 & 24,2 & 26 & 31,1 \\
$\begin{array}{l}\text { Türkiye Prim } \\
\text { Üretimi }\end{array}$ & & & & \\
\hline
\end{tabular}

Kaynak: T.C. Hazine Müsteşarlığı, Sigortacılık ve BES Faaliyet Raporu 2015

Global nitelikteki sigortacılık sektörü Türkiye gibi piyasa oynaklığının fazla olduğu ülkelerde oldukça önemli bir paya sahip olmakla birlikte aynı zamanda bir tasarruf aracı olarak da kullanılabilmektedir. Bu sayede sigorta primleri değerlendirilerek yatırımlara kaynak oluşturacak fon arzını da meydana getirebilmektedir. Sigortacılık sistemi ile sosyo-ekonomik krizlerin etkisi azaltılabilmekte, bireylerin başına gelebilecek sosyal ve ekonomik kayılar tazminatlarla giderilebilmektedir. Yatırıma yönlendirilen fonlar sayesinde milli gelir artışı̈ üzerinde pozitif etki sağlayabilmektedir.

Tablo 2

Toplam Sigorta Teminatının GSYH'ye oranı (2011-2015) (Milyar TL)

\begin{tabular}{lccccc}
\hline & $\mathbf{2 0 1 1}$ & $\mathbf{2 0 1 2}$ & $\mathbf{2 0 1 3}$ & $\mathbf{2 0 1 4}$ & $\mathbf{2 0 1 5}$ \\
Verilen Toplam Teminat & $39.163,10$ & $49.714,00$ & $62.820,10$ & $76.526,80$ & $86.059,90$ \\
Hayat Dışı Branşlar & $38.822,40$ & $49.326,20$ & $62.334,30$ & $75.961,90$ & $85.389,10$ \\
Hayat Branşları & 340,60 & 387,80 & 485,70 & 564,90 & 670,80 \\
GSYH (Cari Fiyatlarla) & $1.297,70$ & $1.416,80$ & $1.567,30$ & $1.748,20$ & $1.953,60$ \\
Toplam Teminat/GSYH & 30,18 & 35,09 & 40,08 & 43,78 & 44,05 \\
\hline
\end{tabular}

Kaynak: T.C. Hazine Müsteşarlığı, Sigortacılık ve BES Faaliyet Raporu 2015

Tablo 2'de toplam sigorta teminatının Gayri Safi Yurtiçi Hasılaya oranının önemli büyüklükte olduğu görülmektedir. Yıllar itibari ile bu oranın artışına rağmen halen dünya ortalamalarına göre sektörün büyüme potansiyelinin yüksek olduğu söylenebilir.

\section{Literatür Taraması}

Esra Horasan (2013) ülkemizde 2010 y1lında faaliyet göstermiş olan sigorta şirketlerini analiz etmiş̧ir. Analizde o dönem faaliyet gösteren 34 sigorta şirketinden 32'sini incelemiştir. Yöntem olarak çıktı odaklı veri zarflama analizini kullanmıştır. Çalışmasının amacı Türkiye'deki sigorta şirketlerinin mali bünyelerinin etkinliğini 
incelemektir. Çalı̧̧masında 5 girdi ve 2 çıktı kullanmıştır ve çalışmanın sonucunda Türk sigorta şirketlerinin etkinliklerini arttırmaları gerektiği sonucuna ulaşmıştır. Analizde kullandığı girdiler; likit aktifler, çalışan sayısı, acente sayısı, sabit varlıklar, özsermayedir. Çıktılar ise; üretilen prim miktarı ve teknik sonuçlardır. Sonucunda ortalama etkinlik Charnes, Cooper, Rhodes Veri Zarflama Analizi Modeline (CCR) göre etkinliğin \% 87,1, Banker, Charnes, Cooper Veri Zarflama Analizi Modeline (BCC) göre ise ortalama ölçek etkinliğin \% 89,2 olduğu bulgularına ulaşılmıştır. Kalan \%10,8'lik oranın yani etkin olmayan kısmın etkin olmama sebebi açıklanmıştır. Şirketlerin uygun ölçekte faaliyette bulunmaması ve teknik olarak etkin olunamamasına sebep olan yönetimsel eksiklerden kaynaklanmaktadır. Analiz kapsamında yer alan şirketlerin birçoğunun prim, teknik kâr, mali kâr ve finansal piyasa araçlarına yatırım dengesini kuramadığı bulgularını ortaya koymuştur.

Ufuk Yıldız (2012) çalışmasında Türkiye'de sağlık sigortacıllı̆ı sektöründe faaliyet gösteren 27 sigorta şirketini çıktıya dayalı veri zarflama analizi yöntemiyle incelemiştir. Çalışmasında 6 girdi 3 çıktı kullanmıştır. Girdiler; personel sayısı, acente sayısı, özsermaye, dönen varlıklar, duran varlıklar, aktif toplamdır. Çıktılar; prim üretimleri, teknik kâr, mali kârdır. CCR (Charnes, Cooper, Rhodes Veri Zarflama Analizi Modeli) modeline göre 8, BCC (Banker, Charnes, Cooper Veri Zarflama Analizi Modeli) modeline göre 13 sigorta şirketinin etkin olduğu bulgusuna ulaşmıştır. Ancak belirtilmelidir ki BCC (Banker, Charnes, Cooper Veri Zarflama Analizi Modeli) modeli ile yerel, CCR (Charnes, Cooper, Rhodes Veri Zarflama Analizi Modeli) modeliyle genel teknik verimlilik sonuçlarına ulaşılabilmektedir. Yani bir birimin CCR (Charnes, Cooper, Rhodes Veri Zarflama Analizi Modeli) ile verimli BCC (Banker, Charnes, Cooper Veri Zarflama Analizi Modeli) ile verimsiz olduğu sonucuna ulaşılmış ise o birimin genel olarak etkin ancak yerel olarak etkin olmadığı sonucuna ulaşılmaktadır.

Ali Köse (2010) 2004 ve 2008 yılları arasında faaliyet gösteren hayat/emeklilik şirketini incelemiştir. 2004, 2005 ve 2006 yıllarında 19, 2007 ve 2008 yıllarında faaliyet gösteren 18 şirketi analize dahil etmiştir. Birleşme gösteren şirketleri analize dahil ettiği için karar verme birimleri sayısı bir azalmıştır. Çalışmasında üç girdi iki çıtı olmak üzere toplam beş değişkeni CCR VZA modelini kullanarak incelemiştir. Çalışmanın sonucunda üç şirketin sürekli olduğu diğer şirketlerin ise dönemsel değişiklikler gösterdiği sürekli etkin olmadığı sonucunu ortaya koymuştur.

Mitra Salimi Altan (2010) 2005-2007 arasında ülkemizde faaliyet gösteren 25 sigorta şirketinin etkinliğini analiz etmiş ve sonucunda sigorta şirketlerinin büyük kısmının etkin olmadığını gözlemlemiştir. Çalışmasında 6 girdi 2 çıktı kullanmıştır. Girdiler; nakit ve nakit benzeri varlıklar, maddi varlıklar, finansal varlıklar ile riski sigortaya ait finansal yatırımlar, esas faaliyetlerden borçlar, sigortacılık teknik karş11ıkları (net), ödenmiş sermayedir. Çıktılar; dönem net kâr (+) /zarar (-) ve esas faaliyetlerden alacaklardır. 
Fatma Esin Kılınç (2009) tezinde Türkiye'de hayat, hayat dışı ve emeklilikte faaliyet gösteren 37 sigorta şirketinin 2004, 2005, 2006, 2007 y1llarına ait verilerini çıktıya dönük veri zarflama analiziyle incelemiştir. Veri kümesinde 6 girdi 3 çıktı kullanmıştır. Girdiler; acente sayısı (bankalar hariç), personel sayısı, özsermaye, dönen varlıklar, duran varlıklar, aktif toplamdır. Çıktılar; prim üretimleri, teknik kâr, mali kârdır. Şirketlerin söz konusu yıllara ait etkinlik seyirlerini gözler önüne sermiştir. Zaten etkin olan ve etkin olmayıp etkinliği arttırılması gereken şirketleri belirlemiştir.

Sinem Özbek (2007) T.C. Hazine Müsteşarlı̆̆ı'nın 2004 yılı raporundaki verileri kullanarak sigorta şirketlerinin etkinliğini analiz etmiştir. Çalışmasında girdiye yönelik sabit ölçekli varsayım altında BCC (Banker, Charnes, Cooper Veri Zarflama Analizi Modeli) ve CCR (Charnes, Cooper, Rhodes Veri Zarflama Analizi Modeli) modellerini kurmuştur. Analiz ettiği dönemde ülkemizde bulunan 32 hayat dişı sigorta şirketinden 26 tanesini kullanmıştır. Aynı dönemde ülkemizde faaliyet gösteren toplam 23 hayat ve emeklilik şirketinden 18 tanesini analizine dâhil etmiştir. Bu 18 şirketin 9 tanesi sadece hayat, kalan 9 tanesi ise hem hayat hem de emeklilik alanında faaliyet gösteren şirketlerdir. Çalışmasında 4 girdi ve 3 çıktı kullanmıştır. Kullandığı girdiler; personel sayısı, acente sayısı, sabit varlıklar, özsermayedir. Çıktılar ise; alınan primler, teknik kârlılık, mali kârlılıktır. Elde ettiği bulgulara göre hayat ve hayat/emeklilik alanında girdi odaklı CCR (Charnes, Cooper, Rhodes Veri Zarflama Analizi Modeli) ile 14 sigorta şirketi etkin, 4 tanesi etkinsizdir. Girdi odaklı BCC (Banker, Charnes, Cooper Veri Zarflama Analizi Modeli) yaklaşımı ile 11 etkin 7 sigorta şirketi ise etkin değildir. Hayat dışı sigorta şirketlerinde girdi odaklı CCR (Charnes, Cooper, Rhodes Veri Zarflama Analizi Modeli) modeline göre 15 tanesi etkin, 11 tanesi etkinsiz olduğu sonucuna ulaşmıştır. Girdi odaklı BCC (Banker, Charnes, Cooper Veri Zarflama Analizi Modeli) ile 14 sigorta şirketi etkin, 12 sigorta şirketinin ise etkinsiz olduğu sonucuna ulaşmıştır.

Hale Kirer (2007) gelişmekte olan dinamik bir sektör olduğu için ülkemizdeki sigorta şirketlerinin etkinliğini incelemiştir. Çalışmasında 2006 yılında faaliyet gösteren 24 sigorta şirketinin etkinliğini incelemiştir. Analizde girdi odaklı Ölçeğe Göre Değişken Getiri (VRS) Veri Zarflama Analizi, CRS (Ölçeğe Göre Sabit Getiri) ve Ölçek Etkinlikleri yöntemlerini kullanmıştır. Veri kümesini 3 girdi ve 2 çıktı üzerinden incelemiştir. Girdiler; alınan primler, yatırım gelirleri, özsermayedir. Çıktılar; genel giderler ve toplam sigortacılık teknik karşılıklarıdır. Çalışmasının sonucunda ise ölçeğe göre sabit getiri varsayımı altında 5, değişken getiri yaklaşımında 14 şirket etkin bulmuştur. Ayrıca sektördeki payı yüksek olan 8 tane sigorta şirketinin birisi hariç (Güneş Sigorta A.Ş.) azalan getiriyle çalıştıkları sonucuna ulaşmıştır. Sektörde 2006'da gerçekleşen satın almalarla birlikte \%60'1 yabancı sermayeye ait olan sektörde yabancı sermayeli şirketlerin yerli sermayelilere kıyasla daha etkin olduğunu bulmuştur. Sektörde etkili olan bankaların sigorta şirketi etkinliğinde doğrudan bir etkisinin bulunmadığı sonucuna ulaşmıştır. 
Turgutlu E., Kök R. ve Kasman A. (2007) adlı çalışmalarında 1990-2004 yılları arasında faaliyet göstermiş hayat dışı sigorta şirketlerini incelemişlerdir. Çalışmalarında VZA ve Şans-Kısıtlı Veri Zarflama Analizi (CCDEA) yöntemlerini kullanmışlardır. Çıktılar; ödenen tazminat+teknik karşılıklardır. Girdiler; emek, yardımcı girdiler (fiziksel sermaye dâhil), finansal sermayedir. Analizin sonucunda yıllar içinde yaşanan krizler (1994 ve 1998), Marmara Depremi (1999), sektör düzenlemeleri gibi sebeplerinde etkisiyle belirgin bir etkinsizlik olduğunu göstermişlerdir.

Diboky ve Ubl (2007) 2002-2005 arasında Almanya'da faaliyet gösteren 356 tane sigorta şirketini (20 mütüel şirket ${ }^{1}, 263$ anonim şirket, 20 kamu şirketi) analiz etmişlerdir. Çıktı; net gelirdir. Girdi; emek, işletme sermayesi, finansal borç ve özkaynaktır. Analiz için üç farklı hipotez kurulmuştur. Kurulan hipotezlerin incelenmesi sonucunda Almanya'daki sigorta şirketleri etkinsiz bulunmuştur.

Evrim Turgutlu (2006) veri zarflama analizi, Şans-Kısıtlı Veri Zarflama Analizi (CCDEA), Stokastik Sınır Yaklaşımı (SFA) yöntemlerini kullanmıştır. Kullanılan çıktı; ödenen tazminat + rezervlere yapılan eklemelerdir (teknik karşılıklar). Kullanılan girdiler; emek, yardımcı girdi (fiziksel sermaye dâhil), finansal sermayedir. Çalışmanın sonucunda Türk sigorta sektörüne etkinliğini artırabilmesi için önerilerde bulunmuştur. Sektör etkinliğini VZA ve CCDEA ile daha yüksek bulmuştur.

Demir ve Gençtürk (2006) adlı çalışmalarında 2000-2006 dönemleri arasında faaliyet gösteren bankaların etkinliğini incelemiş ve 2001 kriz dönemi hariç Türkiye'deki bankaların etkinliklerini arttırdığı bulgusunu ortaya koymuştur. Ayrıca bankacılık sektöründe de sigortacılık sektöründe olduğu gibi etkinlik analizi yapılırken sık sık veri zarflama analizi yöntemine başvurulmaktadır.

Kao ve Hwang (2006) çalışmalarında Tayvan'daki 24 hayat dışı sigorta şirketinin 2001 ve 2002 yıllarına ait verilerinin ortalamasını veri zarflama analizi ile incelemiştir.

Cooper, Seiford ve Zhu'nun (2000) iki aşamalı bir tekniğini kullanmışlardır. Bu teknikte girdi çıktı değerlerinin yanı sıra farklı değerlere de yer vermişlerdir. Bu farklı değerlere ara değerler dersek, analizde girdi, ara değer ve çıktılar kullanılmaktadır. Girdiler; üretim maliyeti, sigorta maliyetidir. Ara değerler; direkt yazılan primler, reasürans primleridir. Çıktılar; teknik kâr, yatırım kârıdır. Rasyonel ve bağımsız olmak üzere iki model oluşturdukları çalışmanın sonucunda 24 sigorta şirketinin hiçbirinin her iki aşamada da verimli çalışmadığını gözlemlemişlerdir.

Hwang ve Kao (2006) Tayvan'daki 24 hayat dışı sigorta şirketinin etkinliğini incelemişlerdir. Analizlerinde kullandıkları model Seiford ve Zhu'nun(1999) kullandıkları modeldir. Yapılan analizlere bakıldığında Türkiye gibi gelişmekte olan ülkelerde sigortacılık sektöründe etkinlik ölçümü yapmak için veri zarflama analizi kullanmışlardır.

1 Aynı riske maruz kalan poliçe sahiplerinin yardımlaşma esasına dayanarak karşılıklı sigortacılık yapmak için kullandığı şirket yapılarıdır. İslami sigortacılık yapmak işlemleri için tercih edilir. 
Tone ve Sahoo (2005) 1956'da Hükümet tarafından kurulmuş olan Hindistan Hayat Sigortaları Kurumu'nun (Life Insurance Corporation of India) 19 yıllık süreçteki etkinliğini VZA ile ölçmüştür. İki aşamalı olarak yaptıkları analizde inceledikleri girdiler; iş hizmeti, emek, borç sermaye, eşitsizlik sermayesidir. Ara değerler; üretim maliyeti, sigorta maliyeti, sigortalılara borçlar, rezervlerdir. Çıktı ise tazminattır. Analizin sonucunda kurumun etkinliğinin 1994-1995 y1llarına kadar olan süreçte arttığ 1 ancak yeni teknolojik altyapının hayata geçirildiği dönemden itibaren etkinlik değerlerinin düşmeye başladığını gözlemlemiştir.

Jeng ve Lai (2005) 1985-1994 yılları arasındaki hayat dışı sigorta şirketlerinin etkinliğini incelemişlerdir. Çalışmasında Japonya'daki sigorta şirketleri sınıflandırmalarından birisi olan Keiretsu'yu da kullanmışlardır. Japonya'daki Özelleştirilmiş Bağımlı ve Özelleştirilmemiş Bağımlı hayat dışı sigorta endüstrisine Keiretsu denmektedir. Bu çalışmada da Keiretsu adlı Japonya'daki Özelleştirilmiş Bağımlı ve Özelleştirilmemiş Bağımlı hayat dışı sigorta endüstrilerinde faaliyet gösteren şirketler veri zarflama analizi yöntemiyle incelenmiştir. Girdiler; emek, işletme servisi, sermayedir. Girdi maliyeti; emek maliyeti, işletme servisi maliyeti, sermaye maliyetidir. Çıktılar; kısa dönem poliçe sayısı, uzun dönem poliçe sayısı, korumalı poliçe sayısı, toplam yatırım varlıklarıdır. Yapılan farklı analizlerle Japonya'daki üç farklı sigorta sınıflandırmasının etkinlikleri kendi aralarında karşılaştırılmıştır.

Başkaya Z. ve Akar C. (2005) veri zarflama analizi ile 12 sigorta şirketini analiz etmiştir. Bu 12 şirket 2003 yılında ülkemizdeki sigorta pazarının \%80’ini üretim açısından elinde tutan 12 sigorta şirket olduğu için seçilmiştir. Girdi olarak sigorta şirketlerinin acente sayısı, banka şubesi sayısı, çalışan sayısı kullanılmıştır. Çıktı olarak poliçe adedi ve prim miktarı verilerini incelemiştir. Çalışmanın sonucunda 6 sigorta şirketini etkin diğerlerini etkinsiz olduğu bulgusu elde edilmiştir.

Sezen B., İnce H. ve Aren S. (2005) 1998-2003 yılları arasında ülkemizde faaliyet göstermiş olan hayat dışı sigorta şirketlerini incelemiştir. Çalışmada kullanılmış olan girdiler; toplam giderler, özkaynaklar ve borçlar toplamıdır. Çıktılar ise teknik karşılıkların toplam değeri ve ödenen tazminatlar toplamıdır. Sonucunda en yüksek ortalama etkinlik düzeylerinin 1998-1999-2003 yıllarında büyük ölçekli şirketlere ait olduğunu 2000-20012002 yıllarında ise orta ölçekli sigorta şirketlerine ait olduğu bulgularına ulaşılmıştır.

Kılıçkaplan ve Baştürk (2004) 2002 yılında Türkiye'de hayat dışı alanda faaliyet gösteren 30 sigorta şirketini çıktı odaklı veri zarflama analizi yöntemiyle incelemiştir. Çalışmalarında beş girdi ve üç çıktı kullanmışlardır. Girdiler; personel sayısı, likit aktif, varlıklar, teknik karşılıklar, özsermayedir. Çıktılar; alınan primler, teknik kâr, mali gelirlerdir. Sonuç olarak üç çıktı düzeyinde de aynı anda etkin olan tek bir sigorta şirketi olduğunu gözlemlemişlerdir.

Hakkı Çiftçi (2004) Türk sigorta sektöründe 1998-2000 yılları arasında faaliyet gösteren şirketlerin verilerinin ortalamalarını hem girdi odaklı hem de çıktı odaklı 
veri zarflama analizi yöntemiyle incelemişlerdir. Analizinde kullandığı girdiler; acente sayısı, personel sayısı, sabit varlıklar ve özkaynaktır. Çıktılar; prim üretim miktarı ve teknik faktör değişkenleridir. Çalışmasının sonucunda hayat dışı branşta faaliyet gösteren 41 sigorta şirketinden 11 tanesinin etkin olduğu bulgusunu ortaya koymuştur.

Greene ve Segal (2004) çalışmalarında anonim ve mütüel şirket ayrımı yaparak 19951998 yıllarına ait verileri incelemişlerdir. Verilerini Sigorta Komisyoncuları Ulusal Derneği (The National Association of Insurance Commissioners) yıllık raporlarından elde etmişlerdir. Çalışmalarında dört çıktı ve üç girdi kullanmışlardır. Çıktılar; yatırım, hayat sigortaları, anüite, kaza ve sağlıktır. Uzun Dönem Sigorta Şirketleri Etkinlik ve Boyut: Uluslararası Karşılaştırma" çalışmalarında Standart\&Poors’un 1996-1999 yıllarına ait verilerini kullanmışlardır. Çalışmalarındaki uzun dönem sigortalarına örnek olarak hayat, sağlık ve emekliliği örnek verebiliriz. Çalışmalarında 15 ülkeye ait 4 girdi ve 3 çıktının ortalama değerlerini kullanmışlardır. Girdiler; üretim masrafları, toplam sermaye, teknik rezervler, toplam borçlardır. Çıktılar; genel olarak kazanılmış primler, uzun vadeli sigortalardan kazanılmış primler, yatırım masraflarıdır. Analiz üç farklı şekilde yapılmıştır. Bu analiz şekilleri; teknik, ölçek ve karışık analizlerdir. Karışık analizde teknik analiz ve ölçek analizi birlikte kullanılır. Çalışmanın sonucunda şaşırtıcı bulgular elde edilmiştir. Örneğin; teknik verimliliği yüksek çıkan bazı ülkelerin (İngiltere, İsveç, İspanya, Danimarka) karışık verimlilikleri düşük çıkmıştır.

Sigortacılık sektöründe yer alan firmaların etkinliğinin incelendiği çalışmalara literatürde sıklıkla rastlamak mümkündür. $\mathrm{Bu}$ çalışmalarda genel olarak Veri Zarflama Analizi vb yöntemler kullanılarak değerlendirmeler yapılmıştır. Tablo 3. te sigortacılık sektörü özelinde Veri Zarflama Analizi kullanılarak yapılan başlıca çalışmalara ait bilgiler kısaca özetlenmiştir

\section{Veri Zarflama Analizi}

Etkinlik, var olan girdi miktarı ile olabilecek en fazla çıktıyı almaktır (Farrell, 1957, s. 11). Veri zarflama analizi (VZA) etkinlik ölçümü için göreli analiz kullanılır. Etkinliği analiz edilen birimlere karar verme birimleri (KVB) denir. Sadece analize dâhil edilmiş olan KVB arasında bir değerleme yapar. Yani etkin bulunmuş olan bir KVB, farklı KVB'ler ile yapılan bir analizde etkin sonuç vermeyebilir. VZA yöntemi Farrell'in bir çıktı için yapmış olduğu modelin çok sayıda girdi ve çıktı için uygulanabilen halidir (Karacabey, 2001, s. 4).

Bir etkinlik analizi modeli olarak VZA'nın anlaşılması ve yorumlaması nispeten basittir. Uygulamasında birden çok girdi ve çıktı için çok sayıda KVB'nin analiz edilmesini sağlamaktadır. Bu yönden KVB'lerin çok sayıda olduğu sektörlerde VZA tercih edilen bir yöntemdir. Literatüre baktığımızda bankaların ve sigorta şirketlerinin etkinlik analizi yapılırken çoğunlukla bu yöntem tercih edilmiştir. 
Tablo 3

Sigortacılık Sektöründe Etkinlik Analizine İlişkin Literatür Özeti

\begin{tabular}{|c|c|c|c|c|}
\hline $\begin{array}{l}\text { Yazar ve } \\
\text { Yil }\end{array}$ & Model & Girdiler & Çıktılar & Bulgular \\
\hline $\begin{array}{l}\text { Esra } \\
\text { Horasan } \\
(2013)\end{array}$ & $\begin{array}{l}\text { Çıktı Odaklı } \\
\text { VZA }\end{array}$ & $\begin{array}{l}\text { Likit Aktif } \\
\text { Çalışan Sayısı } \\
\text { Acente Sayısı } \\
\text { Sabit Varlık } \\
\text { Özsermaye }\end{array}$ & $\begin{array}{l}\text { Prim } \\
\text { Teknik Sonuç }\end{array}$ & $\begin{array}{l}\text { CCR Modeline göre } \% 87,1 \text { etkin } \\
\text { BCC Modeline göe } \% 89,2 \text { etkin } \\
\text { bulunmuştur }\end{array}$ \\
\hline $\begin{array}{l}\text { Ufuk Yildız } \\
(2012)\end{array}$ & $\begin{array}{l}\text { Çıktı Odaklı } \\
\text { VZA }\end{array}$ & $\begin{array}{l}\text { Personel Sayısı } \\
\text { Acente Sayısı } \\
\text { Özsermaye } \\
\text { Dönen Varlık } \\
\text { Duran Varlık } \\
\text { Aktif Toplam }\end{array}$ & $\begin{array}{l}\text { Prim } \\
\text { Teknik Kâr } \\
\text { Mali Kâr }\end{array}$ & $\begin{array}{l}\text { CCR Modeline göre } \% 27,58 \text { etkin } \\
\text { BCC Modeline göre } \% 44,82 \text { etkin } \\
\text { bulunmuştur. }\end{array}$ \\
\hline $\begin{array}{l}\text { Ali Köse } \\
(2010)\end{array}$ & $\begin{array}{l}\text { Girdi Odaklı } \\
\text { VZA }\end{array}$ & $\begin{array}{l}\text { Üretim Elemanı } \\
\text { (Toplam) } \\
\text { Toplam Girdi } \\
\text { Toplam } \\
\text { Özsermaye }\end{array}$ & $\begin{array}{l}\text { Prim } \\
\text { Toplam Gelirler }\end{array}$ & $\begin{array}{l}\text { 2004, } 2005 \text { ve } 2006 \text { y1llarında } 19, \\
2007 \text { ve } 2008 \text { y1llarında faaliyet } \\
\text { gösteren } 18 \text { hayat/emeklilik şirketin } \\
\text { analize dâhil etmiştir. Ortalama } \\
\text { sürekli etkinlik \% } 84 \text { bulunurken } \\
\text { sadece üç şirketin sürekli etkin } \\
\text { olduğu tespit edilmiştir. }\end{array}$ \\
\hline
\end{tabular}

Nakit ve Nakit

Benzeri Varlıklar

Maddi Varlıklar

Finansal Varlıklar

Mitra

$\begin{array}{ll}\text { Salimi } & \text { Çıktı Odaklı } \\ \text { Altan } & \text { VZA } \\ (2010) & \end{array}$

Fatma Esin

Kılınç

(2009)

Çıktı Odaklı

VZA

$\begin{array}{ll}\text { Sinem } & \text { Girdi Odaklı } \\ \text { Özbek ( } & \text { VZA } \\ \text { 2007) } & \end{array}$

Hale Kirer Girdi Odaklı (2007) ile Riski Sigortaya

Ait Finansal

Yatırımlar

Esas

Faaliyetlerden

Borçlar

Sigortacılık Teknik

Karşılıkları

Ödenmiş Sermaye

Acente Sayısı (Bankalar Hariç)

Personel Sayısı

Özsermaye

Dönen Varlıklar

Duran Varliklar

Aktif Toplam

Personel Sayısı

Acente Sayıs1

Sabit Varlıklar

Özsermaye

Alınan Primler Yatırım Gelirleri Özsermaye
Dönem Net Kâr

(+) /

Zarar (-)

Esas

Faaliyetlerden

Alacaklar

Prim Üretimleri

Teknik Kâr

Mali Kâr

Alınan Primler

Teknik Kâr

Mali Kâr

Genel Girdiler

Teknik

Karrşılıklar
2005-2007 arası üç yıllık olarak 25 hayat dışı şirketi analiz etmiştir. Süper etkinlik yöntemini kullanmıştır. 2005'te 16, 2006'da 14, 2007 'de 15 tanesinin etkinsiz olduğu sonucunu ortaya koymuştur.

21 adet hayat dişı ve 16 adet hayat ve emeklilik şirketini incelemiştir. 2005 $17 \mathrm{HD}$ ve $12 \mathrm{H} / \mathrm{E}, 2006$ ' da $20 \mathrm{HD}$ ve $10 \mathrm{H} / \mathrm{E}, 2007$ 'de $18 \mathrm{HD}$ ve $8 \mathrm{H} / \mathrm{E}$ şirketini etkin bulmuştur.

2004 yılında faaliyet göstermiş olan sigorta şirketlerini analiz etmiş. CCR Modeline göre 15, BCC Modeline göre 14'ü etkin bulunmuştur.

2006 yılında faaliyet gösteren 24 sigorta şirketinin etkinliğini incelemiş ve özellikle yabancı sermayeli şirketler olmak üzere 14'ünü etkin bulmuştur. 
Turgutlu, Kök ve

Kasman (2007)

$\begin{array}{ll} & \text { Şans-Kısıtlı } \\ \text { Evrim } & \text { VZA (CCDEA) } \\ \text { Turgutlu } & \text { Stokastik Sınır } \\ \text { (2006) } & \text { Yaklaşımı } \\ & \text { (SFA) }\end{array}$

Diboky ve

Ubl (2007)

VZA

Cooper,

Seiford ve

Zhu (2000)

Tone ve

Sahoo

(2006)

Jeng ve Lai (2005)

VZA

Başkaya ve

Akar (2005)

Sezen, İnce

ve Aren

(2005)

Kılıçkaplan ve Baștürk (2004)

VZA

VZA

$\begin{array}{lcl}\text { Şans-Kısıtlı } & \text { Ödenen Tazminat } & \text { Yardımek } \\ \text { VZA (CCDEA) } & \text { Teknik Karşılıklar } & \text { Finansal } \\ \text { ve VZA } & & \text { Sermaye }\end{array}$

Emek

İşletme Sermayesi

Finansal Borç

Özkaynak

Üretim Maliyeti

Sigorta Maliyeti

Üretim Maliyeti

Sigorta Maliyeti

Teknik Kâr

Yatırım Kârı

Tazminat

Kisa Dönem

Poliçe Sayısı

Uzun Dönem

Poliçe Sayısı

Korumalı Poliçe

Sayıs1

Toplam Yatırım

Varlıkları

Acente Sayıs1

Banka Şubesi

Sayısı

Çalışan Sayısı

Toplam Girdi

Özkaynak

Toplam Borç

Personel Sayısı

Likit Aktif

Varlıklar

Teknik Karşılıklar

Özsermaye Prim Miktarı

Teknik Karşılıklar Tazminat

Alınan Primler Teknik Kâr Mali Gelirler
1990-2004 arasındaki hayat sigorta şirketlerinin ortalama etkinliklerini incelemişlerdir. Aynı verilerle ölçümde CCDEA yönteminin VZA'ya kıyasla daha yüksek sonuçlar verdiğini ortaya koymuştur.

İki farklı uygulama ile analiz etmiștir. VZA ile yapılan analizin sonucunda daha yüksek etkinlik değerleri elde edilmiştir.

2002-2005 arasinda Almanya'da faaliyet gösteren 356 tane sigorta şirketini (20 mütüel, 263 anonim şirket, 20 kamu şirketi) analiz etmişlerdir. Anonim şirketlerin mütüellere kıyasla küçük olmasına rağmen daha etkin olduğu sonucuna varmıştır.

24 adet sigorta şirketini incelemiştir. Ancak her iki aşamada da etkin bulunan sigorta şirketi olmamıştır.

Hindistan Hayat Sigortaları Kurumu'nun 19 yıllık etkinliğini incelemişlerdir. (1982-1983'ten 2000-2001'e) 1994-1995 döneminde düşüş trendi görülmüştür.

Japonya'daki 1985-1994

yılları arasındaki sigorta şirketi sınıflandırmaları içindeki şirketlerinin etkinliğini karşılaştırmış. Bağımsız ve Keiretsu (Keiretsu şirketler, Japon sigorta şirketi sinıflandırmalarından birisidir.) ve bağımsız şirketleri sınıflandırarak incelemiştir. Bağımsız ve Keiretsu etkinlik düzeyleri benzer düzeyde gerçekleşmiştir.

2003 'te Türkiye sigorta pazarının Poliçe Adedi $\quad$ \%80'ini elinde bulunduran 12 şirketi analiz etmiştir. 6'sını etkin bulmuştur.

28 Hayat dışı sigorta şirketini incelemiș ve 1998'de 7, 1999'da 4, 2000'de 7, 2001'de 5, 2002'de 8, 2003 'te 11 tanesinin etkin olduğu sonucuna ulaşmıştır.

2002'de Türkiye'de faaliyet gösteren 30 hayat dışı şirketleri incelemiştir. Tüm çıktılar için 8 şirket etkin bulunmuștur. 


\begin{tabular}{|c|c|c|c|c|}
\hline $\begin{array}{l}\text { Hakk1 Çiftçi } \\
(2004)\end{array}$ & $\begin{array}{l}\text { Girdi Odaklı } \\
\text { VZA ve Çıktı } \\
\text { Odaklı VZA }\end{array}$ & $\begin{array}{l}\text { Acente Sayısı } \\
\text { Personel Sayısı } \\
\text { Sabit Varlıklar } \\
\text { Özkaynak }\end{array}$ & $\begin{array}{l}\text { Prim } \\
\text { Teknik Faktör } \\
\text { Değişkenleri }\end{array}$ & $\begin{array}{l}\text { 1998-2000 arasında faaliyet } \\
\text { göstermiş olan } 41 \text { hayat dişı sigorta } \\
\text { şirketinin } 11 \text { tanesinin etkin olduğu } \\
\text { sonucuna ulaşmıştır. }\end{array}$ \\
\hline $\begin{array}{l}\text { Greene } \\
\text { ve Segal } \\
(2004)\end{array}$ & $\begin{array}{l}\text { Teknik Etkinlik } \\
\text { Ölçek Etkinlik } \\
\text { Karışık } \\
\text { Etkinlik }\end{array}$ & $\begin{array}{l}\text { Üretim Masrafları } \\
\text { Toplam Sermaye } \\
\text { Teknik Rezervler } \\
\text { Toplam Borçlar }\end{array}$ & $\begin{array}{l}\text { Kazanılmış } \\
\text { Primler } \\
\text { Uzun Vadeli } \\
\text { Sigortalardan } \\
\text { Kazanılmış } \\
\text { Primler } \\
\text { Yatırım } \\
\text { Masrafları }\end{array}$ & $\begin{array}{l}\text { 1995-1998 yıları arasında } 15 \\
\text { ülkedeki hayat sigorta şirketi } \\
\text { verilerini anonim ve mütüel ayrımı } \\
\text { yaparak incelenmişlerdir. } \\
\text { Sektörün \%20'sinin etkinsiz olduğu } \\
\text { sonucuna varmıştır. }\end{array}$ \\
\hline
\end{tabular}

VZA parametrik olmayan bir yöntemdir. VZA birçok KVB'nin aynı anda etkinliğinin ölçülmesine imkân sağlamaktadır. Bu sebeple homojen karar birimleri için etkinlik analizi yapılırken tercih edilen bir yöntemdir.

\subsection{Girdilerin ve Çıktıların Belirlenmesi}

VZA'da girdi-çıktı değişkenlerinin seçilmesi önem teşkil eden bir aşamadır. Çünkü farklı girdi-çıktılarla yapılan analizin sonucunda farklı etkinlik değerleri elde edilebilir. Bu sebeple sektörle ilgili en geniş kapsamlı sonuçların elde edilmesini sağlayacak değişkenlerin seçilmesine özen gösterilmelidir. Birbiriyle ilişkili olmayan girdi-çıktıların belirlenerek analiz edilmesi halinde etkinlik skorları hatalı çıkabilir. Hatta analizin sonucunda sektör içinde etkin olması gereken bir şirketin, etkinsiz olduğu sonucu elde edilebilir.

$\mathrm{Bu}$ analizde girdi ve çıktılar belirlenirken literatür göz önünde bulundurulmuştur. Tablo 4'te görüldüğü üzere sigorta sektörünün temel gelir kaynağı olan prim ve kâr/zarar dengesi çıktı olarak belirlenmiştir. Üretimde kullanılan elemanların şirket bünyesinde çalışanları, bilançodan elde edilmiş olan toplam varlık ve özkaynak ile sigorta şirketinin en büyük gider kalemi olan tazminat girdi olarak belirlenmiştir.

Çalışmanın güvenilirliği açısından VZA'da yer alan tüm KVB için girdi-çıktı değerlerinin ulaşılabilir olması gerekmektedir. Analizde kullanılan veriler T.C. Başbakanlık Hazine Müsteşarlığı'nın yayınladığı "Sigortacılık ve Bireysel Emeklilik Raporlarından" elde edilmiştir.

\subsection{VZA Modelinin Belirlenmesi}

Veri Zarflama Analizinin, CCR model, BCC model ve Toplamsal modeli olmak üzere üç farklı türü vardır.

CCR Modeli, Charnes, Chooper ve Rhodes geliştirmiştir. Ölçeğe göre sabit getiri (ÖSG) varsayımına dayanan ve doğrusal bir VZA modelidir (A.Charnes, W.W.Cooper, \& E.Rhodes, 1978, s. 430). CCR Modelinin girdi odaklı ve çıktı odaklı olmak üzere türleri vardır (Depren, 2008, s. 30). BCC Modeli ise Banker, Charnes 
ve Cooper'ın geliştirdikleri model Ölçeğe Göre Değişken Getiri Varsayımına (ÖDG) dayanır. BCC Modeli de girdi odaklı BCC ve çıktı odaklı BCC olarak ikiye ayrılır. Toplamsal Model ise yönelimsiz modeldir (Yücel, 2017, s. 20). Girdi veya çıktı odaklı olarak yapılmaz. Model çıktı miktarını arttırmaya yönelik çalışırken aynı zamanda girdi miktarını azaltmaya yönelik sonuçlar verir. T. Coelli tarafından geliştirilmiştir (Ishizaka \& Nemer, 2013, s. 252).

Literatüre bakıldığında ÖSG varsayımı altında CCR VZA Modelinin kullanıldığı görülmektedir. $\mathrm{Bu}$ çalışmada ÖSG varsayımı kullanılmasına karar verilmiştir. ÖSG varsayımına dayanan VZA modeli CCR'dır. Ancak CCR modelinin girdiye yönelik olarak mı çıktıya yönelik olarak mı yapılmasına karar vermek için toplamsal model kullanılmıştır. Toplamsal model yönelimsiz olduğu için, analiz sonuçlarına göre çıktı odaklı CCR veya girdi odaklı CCR modellerinden hangisinin kullanılacağına karar verilmiştir. Coelli'nin çalışmasına göre geliştirilmiş Win4DEAP 2 Programı kullanılmıştır. Analiz girdilerden ziyade çıktılar üzerinde değişiklik yapılmasına yönelik sonuçlar vermiştir. Böylece CCR VZA modelinin çıktı odaklı olarak yapılmasına karar verilmiştir. Yine veriler Win4DEAP 2 Programı kullanılarak analiz edilmiştir.

\section{Uygulama}

Belirlenen çıktı odaklı CCR VZA Modeline göre, 2011-2015 y1lları arasında faaliyet göstermiş olan 30 sigorta şirketi analiz edilmiş ve Tablo 5 'teki sonuçlar elde edilmiştir.

2011, 2012, 2013, 2014 ve 2015 yıllarının her biri için ayrı ayrı analiz yapılmıştır. Sonuçlar Tablo 4'te biraraya getirilmiştir.

Tablo 4

Analiz İçin Belirlenen Girdi ve Çıktılar

\begin{tabular}{|c|c|c|c|c|}
\hline Girdi (I) & Üretim Elemanı (Adet) & Aktif Toplam (TL) & Özkaynak (TL) & Tazminat (TL) \\
\hline Çıktı (O) & Teknik Denge (TL) & Prim (TL) & & \\
\hline
\end{tabular}

Tablo 5'te hem yıl temelli olarak, etkin bulunmuş olan hayat dışı sigorta şirketlerinin adedi hem de şirketlerinin etkinlik yüzdeleri gösterilmiştir. Tablo 5'e göre 20112015 yılları arasında analize dâhil edilmiş olan sigorta şirketlerinin çoğunluğu göreli etkinlik sınırının altında kalmıştır.

Etkinlik değeri 1'e ulaşmış olan KVB'lerin kodları Tablo 6'da gösterilmektedir. Ayrıca etkin KVB'lerin, adetleri ve yüzdeleri yıllara göre sinıflandırılarak sıralanmıştır. Ancak Tablo 6'da etkin olarak sıralanan KVB'ler her yıl kendi içindeki değerlendirmenin sonucu olarak bulunmuştur. Yani etkin sınıra ulaşmış olan bir KVB, farklı sigorta şirketlerinin içinde değerlendirmiş olsaydı etkin sonuç vermeyebilirdi. Çünkü VZA bir göreli etkilik analizidir. 
Tablo 5

Çıktı Odaklı CCR VZA Modeli Etkinlik Sonuçları (2011-2015)

\begin{tabular}{|c|c|c|c|c|c|}
\hline KVB & 2011 & 2012 & 2013 & 2014 & 2015 \\
\hline A1 & 1,000 & 1,000 & 0,955 & 0,928 & 1,000 \\
\hline A2 & 0,586 & 0,659 & 0,611 & 0,673 & 0,628 \\
\hline A 3 & 0,564 & 0,523 & 0,602 & 0,555 & 0,481 \\
\hline A4 & 0,542 & 0,622 & 0,529 & 0,523 & 0,500 \\
\hline A5 & 0,413 & 0,457 & 0,519 & 0,557 & 0,393 \\
\hline A6 & 0,629 & 0,668 & 0,350 & 0,621 & 1,000 \\
\hline A7 & 0,493 & 0,627 & 0,463 & 0,418 & 0,409 \\
\hline A 8 & 0,681 & 1,000 & 0,643 & 0,542 & 0,510 \\
\hline A9 & 0,773 & 1,000 & 1,000 & 1,000 & 1,000 \\
\hline A10 & 0,594 & 0,767 & 0,981 & 0,688 & 0,770 \\
\hline A11 & 0,650 & 0,743 & 0,500 & 0,558 & 1,000 \\
\hline A12 & 1,000 & 1,000 & 0,481 & 0,622 & 0,677 \\
\hline A13 & 0,501 & 0,627 & 0,395 & 0,422 & 0,557 \\
\hline A14 & 1,000 & 1,000 & 0,842 & 0,735 & 1,000 \\
\hline A 15 & 0,566 & 0,642 & 0,508 & 0,490 & 0,494 \\
\hline A16 & 0,568 & 0,542 & 0,520 & 0,665 & 0,897 \\
\hline A17 & 0,416 & 0,405 & 0,414 & 0,424 & 0,525 \\
\hline A18 & 0,589 & 0,587 & 0,550 & 0,581 & 0,632 \\
\hline A19 & 0,627 & 0,649 & 0,586 & 0,563 & 0,654 \\
\hline A20 & 0,542 & 0,642 & 0,614 & 0,517 & 0,492 \\
\hline A21 & 0,354 & 1,000 & 0,338 & 0,304 & 0,460 \\
\hline A22 & 0,348 & 0,478 & 0,541 & 0,556 & 0,607 \\
\hline A 23 & 0,666 & 0,732 & 0,784 & 0,755 & 0,643 \\
\hline A24 & 0,516 & 0,593 & 0,571 & 0,616 & 0,676 \\
\hline A 25 & 1,000 & 1,000 & 1,000 & 0,838 & 0,607 \\
\hline A26 & 0,460 & 0,518 & 0,508 & 0,531 & 0,578 \\
\hline A 27 & 1,000 & 1,000 & 1,000 & 1,000 & 1,000 \\
\hline A28 & 0,784 & 0,991 & 0,539 & 0,669 & 0,779 \\
\hline A29 & 1,000 & 1,000 & 1,000 & 1,000 & 1,000 \\
\hline A30 & 0,586 & 0,531 & 0,642 & 0,783 & 0,446 \\
\hline
\end{tabular}

Tablo 5

Etkin Bulunan KVB'lerin Adedi ve Yüzdeleri (2011-2015)

\begin{tabular}{lccccc}
\hline & $\mathbf{2 0 1 1}$ & $\mathbf{2 0 1 2}$ & $\mathbf{2 0 1 3}$ & $\mathbf{2 0 1 4}$ & $\mathbf{2 0 1 5}$ \\
\hline Adet & 6 & 9 & 4 & 3 & 7 \\
Yüzde & 20,00 & 30,00 & 13,33 & 10,00 & 23,33 \\
\hline
\end{tabular}

Tablo 7'de çıktı odaklı CCR Modeline göre analiz edilmiş olan KVB'ler etkinlik dereceleri gösterilerek sıralanmıştır. Aynı zamanda Tablo 7'de ortalama etkinlik düzeyinin üzerinde kalan ve etkin sonuca ulaşmış olan KVB'lerin kodları koyu yazılarak gösterilmiştir. 
Tablo 6

Etkin Bulunan Karar Verme Birimleri (2011-2015)

\begin{tabular}{lcccc}
\hline $\mathbf{2 0 1 1}$ & $\mathbf{2 0 1 2}$ & $\mathbf{2 0 1 3}$ & $\mathbf{2 0 1 4}$ & $\mathbf{2 0 1 5}$ \\
\hline A1 & A1 & A9 & A9 & A1 \\
A12 & A12 & A25 & A27 & A6 \\
A14 & A8 & A27 & A29 & A9 \\
A25 & A9 & A29 & & A11 \\
A27 & A14 & & A14 \\
A29 & A21 & & A27 \\
& A25 & & A29 \\
& A27 & & \\
\hline
\end{tabular}

Tablo 7

Çıktı Odaklı CCR Modeline Göre Etkinlik Stralaması ve Dereceleri (2011-2015)

\begin{tabular}{|c|c|c|c|c|c|c|c|c|c|}
\hline \multirow{2}{*}{$\begin{array}{c}2011 \\
\text { KVB }\end{array}$} & \multirow[b]{2}{*}{$\begin{array}{l}\text { Etkinlik } \\
\text { Derecesi }\end{array}$} & \multicolumn{2}{|c|}{2012} & \multicolumn{2}{|c|}{2013} & \multicolumn{2}{|c|}{2014} & \multicolumn{2}{|c|}{2015} \\
\hline & & KVB & $\begin{array}{l}\text { Etkinlik } \\
\text { Derecesi }\end{array}$ & KVB & $\begin{array}{l}\text { Etkinlik } \\
\text { Derecesi }\end{array}$ & KVB & $\begin{array}{l}\text { Etkinlik } \\
\text { Derecesi }\end{array}$ & KVB & $\begin{array}{l}\text { Etkinlik } \\
\text { Derecesi }\end{array}$ \\
\hline A1 & 1,00 & A1 & 1,00 & A9 & 1,00 & A9 & 1,00 & A1 & 1,00 \\
\hline A12 & 1,00 & A8 & 1,00 & A25 & 1,00 & A27 & 1,00 & A6 & 1,00 \\
\hline A14 & 1,00 & A9 & 1,00 & A27 & 1,00 & A29 & 1,00 & A9 & 1,00 \\
\hline A 25 & 1,00 & A12 & 1,00 & A29 & 1,00 & A1 & 0,93 & A11 & 1,00 \\
\hline A 27 & 1,00 & A14 & 1,00 & A 10 & 0,98 & A25 & 0,84 & A14 & 1,00 \\
\hline A 29 & 1,00 & A21 & 1,00 & A1 & 0,96 & A30 & 0,78 & A27 & 1,00 \\
\hline A28 & 0,78 & A25 & 1,00 & A14 & 0,84 & A23 & 0,76 & A29 & 1,00 \\
\hline A9 & 0,77 & A27 & 1,00 & A23 & 0,78 & A14 & 0,74 & A16 & 0,90 \\
\hline A8 & 0,68 & A29 & 1,00 & A8 & 0,64 & A 10 & 0,69 & A28 & 0,78 \\
\hline A 23 & 0,67 & A28 & 0,99 & A30 & 0,64 & A2 & 0,67 & A 10 & 0,77 \\
\hline A11 & 0,65 & A10 & 0,77 & A20 & 0,61 & A28 & 0,67 & A12 & 0,68 \\
\hline A6 & 0,63 & A11 & 0,74 & $\mathrm{~A} 2$ & 0,61 & A16 & 0,67 & A24 & 0,68 \\
\hline A19 & 0,63 & A23 & 0,73 & A 3 & 0,60 & A12 & 0,62 & A19 & 0,65 \\
\hline A10 & 0,59 & A6 & 0,67 & A19 & 0,59 & A6 & 0,62 & A23 & 0,64 \\
\hline A18 & 0,59 & $\mathrm{~A} 2$ & 0,66 & A24 & 0,57 & A24 & 0,62 & A18 & 0,63 \\
\hline $\mathrm{A} 2$ & 0,59 & A19 & 0,65 & A18 & 0,55 & A18 & 0,58 & $\mathrm{~A} 2$ & 0,63 \\
\hline A 30 & 0,59 & A 15 & 0,64 & A22 & 0,54 & A19 & 0,56 & A22 & 0,61 \\
\hline A16 & 0,57 & A20 & 0,64 & A28 & 0,54 & A11 & 0,56 & A 25 & 0,61 \\
\hline A15 & 0,57 & A7 & 0,63 & A4 & 0,53 & A5 & 0,56 & A26 & 0,58 \\
\hline A 3 & 0,56 & A13 & 0,63 & A16 & 0,52 & A22 & 0,56 & A13 & 0,56 \\
\hline A4 & 0,54 & A4 & 0,62 & A5 & 0,52 & A3 & 0,56 & A17 & 0,53 \\
\hline A 20 & 0,54 & A24 & 0,59 & A15 & 0,51 & A8 & 0,54 & A8 & 0,51 \\
\hline A24 & 0,52 & A18 & 0,59 & A26 & 0,51 & A26 & 0,53 & A4 & 0,50 \\
\hline A13 & 0,50 & A16 & 0,54 & A11 & 0,50 & A4 & 0,52 & A15 & 0,49 \\
\hline A7 & 0,49 & A30 & 0,53 & A12 & 0,48 & A20 & 0,52 & A20 & 0,49 \\
\hline A26 & 0,46 & A3 & 0,52 & A7 & 0,46 & A15 & 0,49 & A 3 & 0,48 \\
\hline A17 & 0,42 & A26 & 0,52 & A17 & 0,41 & A17 & 0,42 & A21 & 0,46 \\
\hline A5 & 0,41 & A22 & 0,48 & A13 & 0,40 & A13 & 0,42 & A30 & 0,45 \\
\hline A21 & 0,35 & A5 & 0,46 & A6 & 0,35 & A7 & 0,42 & A7 & 0,41 \\
\hline A 22 & 0,35 & A17 & 0,41 & A21 & 0,34 & A21 & 0,30 & A5 & 0,39 \\
\hline
\end{tabular}


Her yıla ait ortalama etkinlik değeri tablo 8'de gösterilmektedir. Tablo 8'e göre 2011 y1lı ortalama etkinlik değeri 0,648, 2012 y1lı ortalama etkinlik değeri 0,734, 2013 y1lı ortalama etkinlik değeri 0,633, 2014 y1lı ortalama etkinlik değeri 0,638, 2015 yılı ortalama etkinlik değeri 0,680'dir. Bu değerlere göre sektördeki şirketlere ait ortalama etkinlik değeri beş yıl boyunca büyük oranda değişiklik göstermemiştir. Ancak bununla birlikte beş yıllık sürenin sonucunda sektördeki hayat dişı sigorta şirketlerinin ortalama etkinlik değerlerinde artış gerçekleşmiştir.

Tablo 8

Çıktı Odaklı CCR VZA'ya Göre Ortalama Etkinlik Değeri (2011-2015)

\begin{tabular}{llllll}
\hline & $\mathbf{2 0 1 1}$ & $\mathbf{2 0 1 2}$ & $\mathbf{2 0 1 3}$ & $\mathbf{2 0 1 4}$ & $\mathbf{2 0 1 5}$ \\
\hline Ortalama Etkinlik Değeri & 0,648 & 0,734 & 0,633 & 0,638 & 0,680
\end{tabular}

Tablo 9

Çıktı Odaklı CCR Modeline Göre Etkinlik Siralaması (2011-2015)

\begin{tabular}{|c|c|c|c|c|c|}
\hline Sura & 2011 & 2012 & 2013 & 2014 & 2015 \\
\hline 1 & $\mathrm{~A} 1$ & A1 & A9 & A9 & A1 \\
\hline 2 & A12 & A8 & A25 & A27 & A6 \\
\hline 3 & A14 & A9 & A 27 & A29 & A9 \\
\hline 4 & A 25 & A 12 & A29 & $\mathrm{A} 1$ & A11 \\
\hline 5 & A27 & A14 & A 10 & A25 & A14 \\
\hline 6 & A29 & A21 & A1 & A30 & A27 \\
\hline 7 & A 28 & A 25 & A 14 & A 23 & A29 \\
\hline 8 & A9 & $\mathrm{A} 27$ & A 23 & A14 & A16 \\
\hline 9 & A8 & A 29 & A8 & A 10 & A28 \\
\hline 10 & A23 & A28 & A30 & $\mathrm{A} 2$ & A10 \\
\hline 11 & A11 & A 10 & A 20 & A 28 & A 12 \\
\hline 12 & A6 & A11 & $\mathrm{A} 2$ & A16 & A24 \\
\hline 13 & A19 & A23 & A3 & A12 & A19 \\
\hline 14 & A 10 & A6 & A19 & A6 & A23 \\
\hline 15 & A18 & $\mathrm{A} 2$ & A24 & A24 & A18 \\
\hline 16 & A2 & A19 & A18 & A18 & A2 \\
\hline 17 & A 30 & A 15 & A22 & A19 & A 22 \\
\hline 18 & A16 & A 20 & A28 & A11 & A 25 \\
\hline 19 & A 15 & A7 & A4 & A5 & A 26 \\
\hline 20 & $\mathrm{~A} 3$ & $\mathrm{~A} 13$ & A16 & $\mathrm{A} 22$ & A13 \\
\hline 21 & A4 & A4 & A5 & A3 & A17 \\
\hline 22 & A 20 & A24 & A 15 & A8 & A8 \\
\hline 23 & A24 & A18 & A26 & A26 & A4 \\
\hline 24 & A 13 & A 16 & A11 & $\mathrm{A} 4$ & A 15 \\
\hline 25 & $\mathrm{~A} 7$ & A 30 & A 12 & A20 & A 20 \\
\hline 26 & A 26 & A3 & A7 & A15 & A3 \\
\hline 27 & A 17 & A26 & A 17 & A17 & $\mathrm{A} 21$ \\
\hline 28 & A5 & A22 & A 13 & A13 & A30 \\
\hline 29 & A21 & A5 & A6 & A7 & A7 \\
\hline 30 & A 22 & A 17 & A 21 & A21 & A5 \\
\hline
\end{tabular}


Tablo 9'da hayat dışı sigorta sektöründe faaliyet gösteren sigorta şirketleri etkinlik düzeyi yüksekten düşüğe doğru sıralanmıştır. Tablo 19' da koyu olarak belirtilmiş olan kodlara sahip şirketler ait olduğu yıllar içerisinde ortalama etkinlik değerinin üzerine çıkmışlardır. Ancak ortalamanın üzerinde olsa bile 1'e ulaşamamış olan KVB'ler VZA'ya göre yine de etkin değildir.

Yukarıdaki Tablo 9'a göre 2011 y1lında A1, A12, A14, A25, A27 ve A29 etkin bulunurken diğer sigorta şirketleri etkinlik sınırına ulaşamamıştır. A28, A9, A8, A23 ve A11 kodlu sigorta şirketleri ise 2011'e ait ortalama etkinlik düzeyini aşan şirketlerdir.

Analize göre 2012 y1lında A1, A8, A9, A12, A14, A21, A25, A27 ve A29 etkin bulunurken diğer sigorta şirketleri etkinlik sınırına ulaşamamıştır. A28, A10 ve A11 kodlu sigorta şirketleri ise 2012'e ait ortalama etkinlik düzeyini aşan şirketlerdir. 2011'de etkin bulunmuş olan şirketlerin yine etkin bulunduğu görülmektedir. Etkin bulunan şirket sayısında bir önceki yıla göre artış yaşanmıştır. 2012'de bir önceki yıla kıyasla göreli etkinlik miktarında artış gözlemlenmiştir.

Analize göre 2013 y1lında A9, A25, A27 ve A29 etkin bulunurken diğer sigorta şirketleri etkinlik sınırına ulaşamamıştır. A10, A1, A14, A23, A8 ve A30 kodlu sigorta şirketleri ise 2013'e ait ortalama etkinlik düzeyini aşan şirketlerdir. Bu yıl etkin bulunmuş olan sigorta şirketlerinin bir önceki yılda etkin bulunmuş olduğu görülmektedir. Ancak 2013'de etkin sektördeki etkin şirket sayısında düşüş gerçekleşmiştir.

Analize göre 2014 y1lında A9, A27 ve A29 etkin bulunurken diğer sigorta şirketleri etkinlik sınırına ulaşamamıştır. A1, A25, A30, A23, A14, A10, A2, A28 ve A16 kodlu sigorta şirketleri ise 2014'e ait ortalama etkinlik düzeyini aşan şirketlerdir. Hayat dış1 sigorta şirketlerinin ortalama etkinlik değeri 2011 ve 2012'ye kıyasla düşük olsa da 2013 yılına göre yükseliş göstermiştir.

Analize göre 2015 y1lında A1, A6, A9, A11, A14, A27 ve A29 etkin bulunurken diğer sigorta şirketleri etkinlik sınırına ulaşamamıştır. A16, A28 ve A10 kodlu sigorta şirketleri ise 2015 'e ait ortalama etkinlik düzeyini aşan şirketlerdir.

\section{Sonuç}

Sigorta sektörüne yönelik olarak bir etkinlik analizi yapılmıştır. Analize dâhil edilen şirketlerin homojen özelliklere sahip olması analizin doğruluğu için önemlidir. Sigorta şirketleri hayat ve hayat dışı olarak sınıflandırılmaktadır. Bu sebeple arasında bir seçim yapılmıştır. Hayat dışı sigorta şirketlerinin sektördeki payı daha yüksek olduğu hayat dışı sigorta şirketleri üzerine bir analiz yapılmıştır.

Analizde kullanmak üzere belirlenmiş olan girdi ve çıktı verileri literatür göz önünde bulundurularak belirlenmiştir. Girdi olarak; üretim elemanı, aktif toplam, özkaynak ve tazminat belirlenmiştir. Çıktı olarak; teknik denge ve prim belirlenmiştir. Türkiye' de 2011- 
2015 yılları arasında faaliyet göstermiş olan hayat dışı sigorta şirketleri incelenmiştir. Beş yıl boyunca verilerinin tamamı bulunan 30 sigorta şirketi tespit edilmiştir.

Literatüre bakıldığında ölçeğe göre sabit getiri varsayımına dayanan CCR VZA modelinin kullanılmasına karar verilmiştir. CCR VZA modeli, çıktı odaklı ve girdi odaklı olmak üzere iki şekilde yapılmaktadır. Çıktı odaklı model, girdi miktarı sabit tutulmaya çalışılarak çıktıların arttırılmasına yönelik sonuçlar verir. Girdi odaklı model, çıktı miktarını sabit tutmaya çalışarak girdi miktarını olabildiğince azaltmaya yönelik sonuçlar verir. Bu çalışmada CCR VZA'nin modellerinden hangisinin kullanılacağına karar vermek için önce toplamsal VZA yöntemiyle analiz yapılmıştır. Toplamsal VZA modelinin sonuçları, girdilerden daha çok çıktılar üzerinde değişiklik yapmaya yönelik sonuçlar vermiştir. Bu sonuçlar doğrultusunda çıktı odaklı CCR VZA modeli uygulanmıştır.

VZA etkinliği göreceli olarak ölçen doğrusal bir yöntemdir. VZA'ya göre en yüksek performansı sergileyen KVB'lerinin etkinlik değeri 1 (Bir) olur. Analiz beş yıla ait veriler için ayrı ayrı yapılmıştır. 2011-2015 yılları arasındaki etkinlik değerleri kendi içinde karşılaştırılmıştır.

Bu 30 sigorta şirketinin birbirlerine göre etkinlikleri değerlendirilmiştir. Ancak VZA dinamik bir yöntem olduğu için etkinlik skorları sadece ölçüm yapıldığı dönemler için geçerlidir. Yapılan çalışmada hayat dişı sigortacılık sektöründe etkin olan ve olmayan şirketler tespit edilmiştir. 30 KVB'nin 18 tanesi 2011-2015 y1lları boyunca hiç etkin sınır olan 1 değerine ulaşamamıştır. 18 adet sigorta şirketine, girdi ve çıktı değerleri üzerinde nasıl değişiklikler yapabileceklerine yönelik önerilerde bulunulmuştur.

Analize göre hayat dişı sigorta sektöründe etkin bulunan şirketlerin analize dâhil edilmiş olan şirketlere oranı \% 10 ile \%30 arasında değişiklik göstermiştir. Etkin bulunan şirket sayısının en çok olduğu yıl 9 karar verme birimi (KVB) ile 2012, en düşük olduğu y1l ise 3 KVB ile 2014'tür. Ancak 2015 yılında etkin şirket sayısı 7'ye çıkarak tekrar yükseliş göstermiştir. 2011'de 6 ve 2013'te 4 sigorta şirketi etkinlik bulunmuştur. Bu durum değerlendirilirken etkin şirket sayısının o yıl içindeki KVB'lerin verilerinden etkilendiğinin göz önünde bulundurulması gerekmektedir. Çünkü yönteme göre diğer KVB'ler içinde en iyi girdi/çıktı değerlerine sahip olan etkin sınıra ulaşmaktadır. Bulgulara göre her yıl etkin sınıra sadece iki sigorta şirketi ulaşmıştır. Sonuç olarak beş yıllık analiz boyunca Türkiye'deki hayat dışı sigorta şirketlerinin etkin olanların sayısının az olduğu ortaya koyulmuştur ve etkinlik sınırına hiç ulaşamamış olanlara etkinliklerini yükseltebilmeleri için önerilerde bulunulmuştur.

Sigorta şirketinin analize dâhil edilmiş olan diğer sigorta şirketleri içindeki durumunu görebilmesi VZA ile etkinliği ölçülen şirketin yararınadır. Ancak VZA bir göreli etkinlik ölçme yöntemi olduğu için farklı KVB'ler ve/veya farklı girdi/ çıktı değerleri kullanılarak analiz yapılırsa etkinlik değerleri değişebilir. Yani aynı 
KVB'ler farklı girdi/çıktı verileriyle analiz edilirse farklı etkinlik değerleri elde ederler. Aynı KVB farklı birimlerle birlikte analiz edilirse birbiri içinde göreli analiz yapıldığ 1 için yine farklı bir etkinlik değerleri elde edebilir. Ayrıca bu çalışmanın sonucunda elde edilmiş olan bulguların Türkiye özel hayat dışı sigortacılık sektörü literatürüne katkı sağlaması beklenmektedir.

\section{Kaynakça}

A.Charnes, W.W.Cooper, \& E.Rhodes. $(1978,11)$. Measuring The Efficiency Of Decision Making Units. European Journal of Operational Research, 2(6), s. 429-444. doi:https://doi. org/10.1016/0377-2217(78)90138-8

Akbay, O. S. (2014). Dünya'da ve Türkiye'de Sigortacılığın Tarihçesi. F. Kaya içinde, Sigortacılık (s. 67-78). İstanbul: Beta Yayınları.

Altan, M. S. (2010). Türk Sigortacılık Sektöründe Etkinlik: Veri Zarflama Analizi Yöntemi ile Bir Uygulama. Gazi Üniversitesi İktisadi ve İdari Bilimler Fakültesi Dergisi, 12(1), s. 185-204.

Başkaya, Z. \& Akar, C. (2005). Sigorta Şirketlerinin Satış Performanslarının Veri Zarflama Analizi Yöntemiyle Belirlenmesi, Muğla Üniversitesi Sosyal Bilimler Enstitüsü Dergisi, 15, s. 37- 51.

Baştürk, F. H., Çakmak, D., \& Demirtaş, B. (2017). Sigortacılı̆̆ı Giriş. Ankara: Bankacılık Akademisi Yayınları.

Cooper, W. W., Seiford, L. M., \& Zhu, J. (2000). A unified additive model approach for evaluating inefficiency and congestion with associated measures in DEA. Socio-Economic Planning Sciences, 34(1), 1-25.

Çiftçi, H. (2004). Türk sigorta sektörünün sorunları; DEA analizi ile Türk sigorta şirketlerinin etkinlik düzeylerinin belirlenmesi. Çukurova Üniversitesi Sosyal Bilimler Enstitüsü Dergisi, 13(1).

Depren, Ö. (2008). Veri Zarflama Analizi ve Bir Uygulama. Yüksek Lisans Tezi. İstanbul.

Diboky, F., \& Ubl, E. (2007, 09). Ownership and efficiency in the German life insurance market: A DEA bootstrap approach. In 34th Seminar of the European Group of Risk and Insurance Economists (EGRIE), June.

Duygulu, E. (2012). Sigorta İşletmeciliği (3 b.). Ankara: Detay Yayıncılık.

Eldelekoğlu, İ. (2012). 6102 Sayılı Türk Ticaret Knaunu Uyarınca Sigorta Ettirenin Prim Ödeme Borcu. İstanbul Ticaret Üniversitesi Sosyal Bilimler Dergisi (22), 203-222.

Farrell, M. J. (1957). Üretim Etkinliği Ölçümü. Journal of the Royal Statistical Society. Series A (General), 120(3), s. 253-290. http://www.jstor.org/stable/2343100 adresinden alınd1

Greene, W. H., \& Segal, D. (2004). Profitability and efficiency in the US life insurance industry. Journal of Productivity Analysis, 21(3), 229-247.

Güzel, A., Okur, A. R., \& Caniklioğlu, N. (2012). Sosyal Güvenlik Hukuku (14 b.). İstanbul: Beta Yayınları.

Horasan, E. (2013). Türkiye'de sigorta şirketlerinin kurumsal yatırımcı olarak finansal piyasalardaki etkinliğinin veri zarflama analizi ile ölçümü (Yüksek Lisans Tezi, Sosyal Bilimler Enstitüsü, Anadolu Üniversitesi, Erzurum) file://C:/Users/ilknur.kulekci/Downloads/326962\%20(3).pdf adresinden alınmıştır

Ishizaka, A., \& Nemer, P. (2013). Multi-criteria Decision Analysis: Methods and Software. West Sussex, İngiltere: J. Wiley. 
Jeng, V., \& Lai, G. C. (2005). Ownership structure, agency costs, specialization, and efficiency: analysis of Keiretsu and independent insurers in the Japanese nonlife insurance industry. Journal of Risk and Insurance, 72(1), 105-158.

Karacabey, A. A. (2001, 07). Veri Zarflama Analizi. A.Ü. SBF GETA Tartışma Metinleri (33).

Karaman, D. (2014). Sigorta ve Risk Kavramları. F. Kaya (Ed.) içinde, Sigortacılık kitabı içinde (s. 7-19). İstanbul: Beta Yayınları.

Kılıçkaplan, S., \& Baştürk, F. H. (2004). Türkiye'de hayat dışı alanda faaliyet gösteren sigorta şirketlerinin 2002 y1lındaki etkinliklerinin veri zarflama analizi ile ölçülmesi. Gazi Üniversitesi İktisadi ve İdari Bilimler Fakültesi Dergisi, 6(2), 63-79.

K1lınç, F. E. (2009). Türk sigortacılık sektörünün veri zarflama analizi yöntemi ile etkinliğinin araştırılması (Doktora Tezi, Süleyman Demirel Üniversitesi, Sosyal Bilimler Enstitüsü, Isparta) file://C:/Users/ilknur.kulekci/Downloads/231642\%20(3).pdf adresinden alınmıştır.

Kırer, H. (2007). Veri zarflama analizi ve sigorta sektörü üzerine bir uygulama (Yüksek Lisans Tezi, Sosyal Bilimler Enstitüsü, Marmara Üniversitesi, İstanbul)

Köse, A. (2010). Türk Sigorta Sektörü Hayat ve Emeklilik Şirketlerinin Etkinlik Analizi, Journal of Academic Studies, 12(44).

Özbek, S. (2007). Sigorta şirketlerinin etkinliğinin veri zarflama analizi ile incelenmesi, (Yüksek Lisans Tezi, Sosyal Bilimler Enstitüsü, Marmara Üniversitesi, İstanbul)

Sezen, B., İnce, H., \& Aren, S. (2005). Türkiye'deki Hayat Dış1 Sigorta Şirketlerinin Veri Zarflama Analizi Tekniği İle Göreli Etkinlik Değerlendirmesi, İktisat İsletme ve Finans, 20(236), 87-95.

Yanık, S. (2016). Sigorta Acentelerinde Yönetim ve Muhasebe Uygulamaları. İstanbul: Türkmen Kitabevi.

Yıldız, U. (2012). Özel sağl1k sigortacılı̆̆ 1 sektöründe faaliyet gösteren şirketlerin veri zarflama analizi ile etkinliğinin ölçülmesi (Yüksek Lisans Tezi, Gaziosmanpaşa Üniversitesi, Sosyal Bilimler Enstitüsü ， Tokat) file://C:/Users/ilknur.kulekci/Downloads/330101\%20(7).pdf adresinden alınmıştır

Yücel, L. İ. (2017). Veri Zarflama Analizi. İstanbul: Der Yayınları.

T.C. Hazine Müsteşarlığı. (2018, 02 02). Sigortacılık ve BES Faaliyet Raporları https://www. hazine.gov.tr/sigortacilik-ve-ozel-emeklilik-raporlari?type=icon adresinden alınmıştır

Tone, K., \& Sahoo, B. K. (2006). Re-examining scale elasticity in DEA. Annals of Operations Research, 145(1), 69-87.

Turgutlu, E. (2006). Tam bilgi ve belirsizlik altında etkinlik analizi: Türk sigortacıllk endüstrisi örneği (1990-2004) (Doktora Tezi, Sosyal Bilimleri Enstitüsü, Dokuz Eylül Üniversitesi, İzmir).

Turgutlu, E., Kök, R., \& Kasman, A. (2007). Türk sigortacılık şirketlerinde etkinlik: Deterministik ve şans kısıtlı veri zarflama analizi. İktisat Işletme ve Finans, 22(251), 85-102. 